University of Nebraska - Lincoln

DigitalCommons@University of Nebraska - Lincoln

\title{
Runoff Loss of Pesticides and Soil: A Comparison between Vegetative Mulch and Plastic Mulch in Vegetable Production Systems
}

\author{
Pamela J. Rice \\ USDA-ARS, price@soils.umn.edu \\ Laura L. McConnell \\ USDA-ARS \\ Lynne P. Heighton \\ USDA-ARS
}

Ali M. Sadeghi

USDA-ARS, ali.sadeghi@ars.usda.gov

Allan R. Isensee

USDA-ARS, aisensee@asrr.arsusda.gov

See next page for additional authors

Follow this and additional works at: https://digitalcommons.unl.edu/usdaarsfacpub

Rice, Pamela J.; McConnell, Laura L.; Heighton, Lynne P.; Sadeghi, Ali M.; Isensee, Allan R.; Teasdale, John R.; Abdul-Baki, Aref A.; Harman-Fetcho, Jennifer A.; and Hapeman, Cathleen J., "Runoff Loss of Pesticides and Soil: A Comparison between Vegetative Mulch and Plastic Mulch in Vegetable Production Systems" (2001). Publications from USDA-ARS / UNL Faculty. 1649.

https://digitalcommons.unl.edu/usdaarsfacpub/1649

This Article is brought to you for free and open access by the U.S. Department of Agriculture: Agricultural Research Service, Lincoln, Nebraska at DigitalCommons@University of Nebraska - Lincoln. It has been accepted for inclusion in Publications from USDA-ARS / UNL Faculty by an authorized administrator of DigitalCommons@University of Nebraska - Lincoln. 


\section{Authors}

Pamela J. Rice, Laura L. McConnell, Lynne P. Heighton, Ali M. Sadeghi, Allan R. Isensee, John R. Teasdale, Aref A. Abdul-Baki, Jennifer A. Harman-Fetcho, and Cathleen J. Hapeman 


\title{
Runoff Loss of Pesticides and Soil: A Comparison between Vegetative Mulch and Plastic Mulch in Vegetable Production Systems
}

\author{
Pamela J. Rice,* Laura L. McConnell, Lynne P. Heighton, Ali M. Sadeghi, Allan R. Isensee, John R. Teasdale, \\ Aref A. Abdul-Baki, Jennifer A. Harman-Fetcho, and Cathleen J. Hapeman*
}

\begin{abstract}
Current vegetable production systems use polyethylene (plastic) mulch and require multiple applications of agrochemicals. During rain events, runoff from vegetable production is enhanced because 50 to $\mathbf{7 5} \%$ of the field is covered with an impervious surface. This study was conducted to quantify off-site movement of soil and pesticides with runoff from tomato (Lycopersicon esculentum Mill.) plots containing polyethylene mulch and a vegetative mulch, hairy vetch (Vicia villosa Roth). Side-by-side field plots were instrumented with automated flow meters and samplers to measure and collect runoff, which was filtered, extracted, and analyzed to determine soil and pesticide loss. Seasonal losses of two to four times more water and at least three times as much sediment were observed from plots with polyethylene mulch (55.4 to $146 \mathrm{~L} \mathrm{~m}^{-2}$ and 247 to $535 \mathrm{~g} \mathrm{~m}^{-2}$, respectively) versus plots with hairy vetch residue (13.7 to $75.7 \mathrm{~L} \mathrm{~m}^{-2}$ and 32.8 to $118 \mathrm{~g}$ $\mathrm{m}^{-2}$, respectively). Geometric means ( \pm standard deviation) of total pesticide loads for chlorothalonil (tetrachloroisophthalonitrile) and $\alpha$ - and $\beta$-endosulfan $(6,7,8,9,10,10$-hexachloro-1,5,5a,6,9,9a-hexahydro6,9-methano-2,4,3-benzodioxathiepin 3-oxide) for a runoff event were 19,6 , and 9 times greater from polyethylene $(800 \pm 4.6,17.6 \pm 3.9$, and $39.1 \pm 4.9 \mu \mathrm{g} \mathrm{m}^{-2}$, respectively) than from hairy vetch mulch plots $\left(42 \pm 6.0,2.8 \pm 5.0\right.$, and $4.3 \pm 4.6 \mu \mathrm{g} \mathrm{m}^{-2}$, respectively) due to greater concentrations and larger runoff volumes. The increased runoff volume, soil loss, and off-site loading of pesticides measured in runoff from the polyethylene mulch suggests that this management practice is less sustainable and may have a harmful effect on the environment.
\end{abstract}

$\mathrm{A}^{\mathrm{c}}$ GRICULTURAL runoff has been implicated in the failure of commercial shell fish farms and in contributing to the Pfiesteria piscicida outbreaks in the MidAtlantic region of the USA. The USEPA estimates that routine agricultural activities are responsible for more than $60 \%$ of the nation's surface water pollution problems (USEPA, 1990). Depending on weather conditions and field slope, as much as $5 \%$ of applied pesticides may be transported in runoff from agricultural fields (Wauchope, 1978). A number of agrochemicals have been detected in surface waters (Baker and Richards, 1990; Johnson et al., 1994) and several studies have demonstrated significant negative effects of agrochemicals on aquatic organisms and ecosystems resulting from nonpoint-source agricultural runoff (Stevenson et al., 1986;

P.J. Rice, USDA-ARS, Soil and Water Management Research, 1991 Upper Buford Circle, St. Paul, MN 55108. L.L. McConnell, L.P. Heighton, A.M. Sadeghi, A.R. Isensee (deceased), A.A. Abdul-Baki, J.A. Harman-Fetcho, and C.J. Hapeman, Environmental Quality Lab., and J.R. Teasdale, Sustainable Agricultural Systems Lab., USDA-ARS, 10300 Baltimore Avenue, Beltsville, MD 20705-2350. Mention of specific products or supplies is for identification and does not imply endorsement by the USDA to the exclusion of other suitable products or suppliers. Received 14 Aug. 2000. *Corresponding authors (price@ soils.umn.edu,hapemanc@ba.ars.usda.gov).

Published in J. Environ. Qual. 30:1808-1821 (2001).
Scott et al., 1990; Chandler and Scott, 1991; Clark et al., 1993; Savitz et al., 1994). In addition, bactericides, insecticides, and fungicides required to protect vegetable crops are known to have adverse effects on finfish, shellfish, and other aquatic organisms at environmentally relevant levels (Scott et al., 1987; Baughman et al., 1989; Pait et al., 1992; Hetzer et al., 1999, 2000).

Tomatoes are one of the most economically important vegetables grown in the USA. The U.S. tomato industry includes both the fresh market and processing tomato industries, which have average annual yields of 3.5 billion pounds (ca. 1.6 billion $\mathrm{kg}$ ) and 9.8 million tons (ca. 8.9 million $\mathrm{Mg}$ ) valued at $\$ 1.1$ billion and $\$ 529$ million, respectively (Davis et al., 1998). Fresh-market vegetable production generally requires polyethylene (plastic) mulch to primarily control weeds and to preserve soil moisture. Use of this impervious mulch on 50 to $75 \%$ of the field may cause large amounts of water to run off the fields with an intense pulse of agrochemicals and sediments during rain events. Research from McCall et al. (1988) and Wan and El-Swaify (1999) have shown greater runoff volumes and soil erosion associated with polyethylene mulch relative to bare soil.

Compared with conventional production agriculture, polyethylene mulch systems have an additional surface for pesticide adsorption-desorption, which may enhance or impede chemical runoff and degradation rates. The sorption of pesticides to plastic will vary depending on the chemical properties of the pesticide and type of plastic. Vuik et al. (1990) reported that etridiazole (5-ethoxy-3-trichloromethyl-1,2,4-thiadiazole), a lipophilic organic fungicide, adsorbed to polyethylene but not to polyvinyl chloride while oxamyl [ $S$-methyl $N^{\prime}, N^{\prime}$-dimethyl- $N$-(methylcarbamoyloxy)-1-thio-oxamimidate], a more polar organic fungicide, did not adsorb to either plastic. Topp and Smith (1992) observed that atrazine (6-chloro- $N^{2}$-ethyl- $N^{4}$-isopropyl-1,3,5-triazine-2,4-diamine), a triazine heribicide, was more readily removed from an aqueous solution with low-density polyethylene than high-density polyethylene. Nerin et al. (1996) reported several organochlorine and organophosphorus pesticides, in an aqueous solution, sorbed to low-density polyethylene after $15 \mathrm{~d}$ of contact time and pesticide degradation was not observed once adsorption occurred.

Vegetative cover crops, particularly hairy vetch, have been shown to be a profitable management practice for fresh-market tomato production resulting in higher tomato yields and lower production costs than polyeth-

Abbreviations: BC, corn grown in bare soil; DOY, day of year; PT, tomatoes grown in polyethylene mulch; $\mathrm{VC}$, corn grown in hairy vetch residue mulch; VT, tomatoes grown in hairy vetch residue mulch. 
ylene mulch or bare soil (Kelly et al., 1995). Gross returns from tomatoes grown in hairy vetch residues were $\$ 700$ to $\$ 13000 \mathrm{ha}^{-1}$ more than from the polyethylene mulch (Kelly et al., 1995). In addition to its economic feasibility, cover crops including hairy vetch have been shown to reduce soil erosion, increase soil organic matter, improve soil tilth (Smith et al., 1987), increase soil infiltration and soil moisture (McVay et al., 1989), act as a slow-release fertilizer (Wagger, 1989; Ranells and Wagger, 1996), and suppress weeds (Teasdale, 1996). Field and laboratory studies have demonstrated that crop residues, vegetative mulches, and vegetative filter strips can reduce runoff, soil erosion, and the off-site transport of pesticides and nutrients from agricultural fields (Ghadiri et al., 1984; Dao, 1991; Sur et al., 1992; Zuzel and Pikul, 1993; Dell et al., 1994; Webster and Shaw, 1996).

This field study was designed to quantitatively compare the off-site movement of soil and agrochemicals from conventional polyethylene mulch and hairy vetch residue plots over three complete growing seasons. Results of this work provided high-quality scientific data to farmers and researchers on the advantages of vegetative mulch systems over polyethylene mulch. The large comprehensive data set will also be valuable in modeling efforts to determine environmental effect of these two production systems on a field or watershed scale.

\section{MATERIALS AND METHODS Site Description}

Runoff water was collected from tomato plots grown under polyethylene and hairy vetch mulch on a study site located at the Henry A. Wallace Beltsville Agricultural Research Center, Beltsville, Maryland (USA). This site was chosen for its slope $(5.2$ to $7.1 \%)$ to facilitate the collection of runoff water. The $2500-\mathrm{m}^{2}$ field is comprised of Mattapex silt loam (fine-silty, mixed, active, mesic Aquic Hapludult with 1.3 to $1.6 \%$ organic carbon content). The site was divided into 16 plots, each with four raised beds ( $15 \mathrm{~cm}$ high, $27 \mathrm{~m}$ long, $0.9 \mathrm{~m}$ wide, and $1.5 \mathrm{~m}$ center-to-center), prepared in a north-south direction. Eight of the 16 plots were equipped with a fiberglass $\mathrm{H}$-flume to capture runoff water. Each flume was equipped with an automated flow meter and runoff sampler containing twenty-four, 300-mL glass bottles (ISCO [Lincoln, NE] Model 6700). Earthen berms were constructed around each plot to prevent water movement between plots. Runoff was collected from the three central rows within each four-bed plot.

\section{Treatments-Management Practices}

Four plots were randomly assigned each of the four treatments using a randomized complete block design. The four treatments included tomatoes grown in polyethylene mulch (PT), tomatoes grown in hairy vetch residue mulch (VT), corn (Zea mays L.) grown in bare soil (BC), and corn grown in hairy vetch residue mulch (VC). Runoff water was collected from the eight plots containing tomato plants. No runoff was collected from the eight plots planted in corn. Tomato and corn plots were rotated annually, PT with BC and VT with VC, to minimize pest pressure.

\section{Plant Cultivation}

In September of 1996, 1997, and 1998, beds in the vegetative mulch treatment plots were constructed and planted with hairy vetch seed inoculated with the appropriate Rhizobium strain. Further information on cultivation of hairy vetch cover crops is given elsewhere (Abdul-Baki et al., 1996; Abdul-Baki and Teasdale, 1997). In early May, the hairy vetch cover crop was killed using a flail-mowing technique (Abdul-Baki and Teasdale, 1997), leaving a finely chopped layer of mulch residue over the soil surface. By mid May, beds for the polyethylene treatments were constructed and drip irrigation lines were installed 8 to $10 \mathrm{~cm}$ from the plant row prior to the installation of the polyethylene.

During the last week of May, 'Sunbeam' tomato plant seedlings were transplanted in the center of each bed with a notillage planter to minimize the disruption of the mulches. Immediately after transplanting, drip lines were added to the surface of the mulch in the VT beds approximately 8 to $10 \mathrm{~cm}$ from the plants. Measured trickle irrigation maintained the plants during dry conditions. Urea fertilizer was dissolved in water and applied to the plots through this irrigation system. As a result of the nitrogen fixing capability of the hairy vetch (Abdul-Baki et al., 1996, 1997) the vegetative mulch plots received one-half of the urea concentration applied to the plastic mulch. Tomato plants grown in the polyethylene and hairy vetch mulch received equal quantities of water through the irrigation system. The quantity of water applied with the trickle irrigation system was not enough to produce surface runoff.

\section{Pesticides}

Pesticides monitored in the experiment were as follows: Lexone DF herbicide (Du Pont, Wilmington, DE) containing $75 \%$ metribuzin [4-amino-6-(1,1-dimethylethyl)-3-(methyl-thio)1,2,4-triazin-5(4H)-one]; Asana XL insecticide (Du Pont) containing $8.4 \%$ esfenvalerate $[(S)$-cyano(3-phenoxyphenyl)methyl $(S)$-4-chloro- $\alpha$-(1-methylethyl)benzeneacetate]; Thiodan 50 WP insecticide (FMC, Philadelphia, PA) containing $50 \%$ endosulfan; Bravo 720 fungicide (ISK Biosciences, Mentor, $\mathrm{OH}$ ) containing 40.4\% chlorothalonil; and Kocide 101 fungicide-bactericide (Aventis, Strasbourg, France) containing $77 \%$ copper hydroxide. Each was applied at recommended rates, which resulted in the application of $42 \mathrm{mg} \mathrm{m}^{-2}$ metribuzin, $3 \mathrm{mg} \mathrm{m}^{-2}$ esfenvalerate, $56 \mathrm{mg} \mathrm{m}^{-2}$ endosulfan, $190 \mathrm{mg} \mathrm{m}^{-2}$ chlorothalonil, and/or $129 \mathrm{mg} \mathrm{m}^{-2}$ copper for each application.

\section{Precipitation Events}

The summers of 1997 and 1998 were exceptionally dry and only 240 and $270 \mathrm{~mm}$ of rain were received during the May to September growing seasons, respectively. Although natural rain events did occur during the experiment, dry soil conditions and small rainfall amounts produced minimal runoff. In order to fully evaluate pesticide losses with runoff under the two agricultural systems, artificial rain events were created with an overhead sprinkler system, when rainfall runoff had not been produced within a week of pesticide applications. The sprinkler system was erected around the field and between the plots with sprinkler nozzles that were $1.8 \mathrm{~m}$ above ground and spaced every $12 \mathrm{~m}$, in order to give a relatively even application of water to all plots simultaneously. This system delivered from 7.5 to $14.3 \mathrm{~mm} \mathrm{~h}^{-1}$ rain intensities to the plots, which is similar to the average natural rainfall intensity $\left(\sim 11 \mathrm{~mm} \mathrm{~h}^{-1}\right)$ during the growing season. Artificial rain events were continued until all plots produced enough runoff water to fill 24 sample bottles. 


\section{Runoff Water Sample Collection and Processing}

The ISCO automated samplers (Model 6700) were equipped with a bubbler flow module (Model 730) that contains a small microprocessor, a compressor, and a differential pressure transducer to measure the water level in the H-flume. The 6700 controller uses the known level-to-flow relationship of the $\mathrm{H}$-flume to calculate the flow rate and total flow from the level measurement. Level-to-flow data were recorded every $5 \mathrm{~min}$ for as long as the flow module detected water in the flume. A tipping-bucket rain gage measured the time and intensity of each rain event. The level-to-flow data from each plot and the field rain gage data provided sufficient information to determine the time to runoff, time of the total runoff event, total runoff volume, and runoff hydrograph (the profile of the water flux intensity over the course of an event) for each plot as well as the total rainfall. The automated samplers were programmed to collect samples on a flow-weighted (volume) basis. The date and time were recorded as the peristaltic pump and distributor arm delivered $300 \mathrm{~mL}$ of runoff to each sample bottle. A total of twenty-four, 300-mL samples can be collected from each event. Water samples were removed from the samplers following the rain event, placed on ice, and transported to the laboratory for immediate processing. Each water sample was characterized for quantity of sediment (total suspended solids) and dissolved-phase pesticide concentrations. A detailed description of the sample processing method is given elsewhere (McConnell et al., 1998).

In order to determine the particle-phase pesticide concentration, $50 \mathrm{~mL}$ from each sample was combined into an integrated sample from each plot for a total of eight integrated samples from each rain event. Integrated samples were filtered through a glass fiber filter (Whatman [Maidstone, UK] GF/F, $0.7-\mu \mathrm{m}$ nominal pore size) using a stainless steel filter holder. Filters were removed, folded to protect particle material, and frozen at $-20^{\circ} \mathrm{C}$ until extraction. Prior to extraction and analysis, each filter paper was weighed and divided into four sections, and the weight of each filter section was recorded. Sections of each filter paper were extracted and analyzed for the applied organic pesticides and copper.

\section{Extraction and Analysis Procedures}

\section{Dissolved-Phase Organic Pesticides}

Due to the small sample volume and the large number of water samples collected in this study, an innovative methodology was required to accurately determine dissolved-phase organic pesticide concentrations. Water samples were extracted and analyzed for metribuzin, chlorothalonil, $\alpha$-endosulfan, and $\beta$-endosulfan using a technique called solid-phase microextraction (SPME) coupled with capillary gas chromatographyelectron capture detection (GC-ECD). A detailed description of the analytical method is given elsewhere (McConnell et al., 1998). Briefly, $1.5 \mathrm{~mL}$ of filtered water $(0.7 \mu \mathrm{m})$ was extracted using a Varian (Palo Alto, CA) SPME III autosampler equipped with either a $100-\mu \mathrm{m}$ polydimethylsiloxane or $85-\mu \mathrm{m}$ polyacrylate fiber (Supelco, Bellefonte, PA) with agitation for $30 \mathrm{~min}$. Analyses were carried out using a Hewlett Packard (Santa Clarita, CA) 5890 Series II gas chromatograph with an electron capture detector. Chromatographic conditions for chlorothalonil and endosulfan analyses were as follows. Column: J\&W Scientific (Folsom, CA) DB-5 column, $30 \mathrm{~m} \times 0.25 \mathrm{~mm}$ i.d., film thickness of $25 \mu \mathrm{m}$. Temperature program: injector temperature $270^{\circ} \mathrm{C}, 150^{\circ} \mathrm{C}$ initial temperature, 2 -min hold, $3^{\circ} \mathrm{C}$ $\mathrm{min}^{-1}$ to $200^{\circ} \mathrm{C}, 5$-min hold, $10^{\circ} \mathrm{C} \min ^{-1}$ to $260^{\circ} \mathrm{C}, 1$-min hold, detector temperature $270^{\circ} \mathrm{C}$. Analyses for metribuzin were carried out using the same chromatographic conditions with the exception of the temperature program, which was as follows: injector temperature $280^{\circ} \mathrm{C}, 100^{\circ} \mathrm{C}$ initial temperature, 2-min hold, $7^{\circ} \mathrm{C} \mathrm{min}^{-1}$ to $260^{\circ} \mathrm{C}$, 4-min hold, detector temperature $280^{\circ} \mathrm{C}$. The limits of detection for the analytes of interest are: chlorothalonil, $3500 \mathrm{ng} \mathrm{L}^{-1}$; $\alpha$-endosulfan, $9.5 \mathrm{ng} \mathrm{L}^{-1}$; $\beta$-endosulfan, $13 \mathrm{ng} \mathrm{L}^{-1}$; and metribuzin, $43 \mathrm{ng} \mathrm{L}^{-1}$.

Fenvalerate and esfenvalerate were extracted from $5 \mathrm{~mL}$ of runoff water using liquid-liquid extraction with three 5-mL aliquots of ethyl acetate. Organic extracts were combined and residual water was removed using a 2 -g column of anhydrous $\mathrm{MgSO}_{4}$ and concentrated to $1 \mathrm{~mL}$ with a gentle stream of high-purity $\mathrm{N}_{2}$ gas and spiked with PCB \#204 (60 ng) as an internal standard. Calibration standards were prepared in deionized water and extracted using the same method as the samples. Deionized water control samples and blank water (5 mL) spiked with $400 \mathrm{ng}$ Asana were extracted along with runoff samples. The limits of detection and extraction efficiencies for fenvalerate and esfenvalerate were $600 \mathrm{ng} \mathrm{L}^{-1}, 96.8 \pm$ $8.9 \%$ and $540 \mathrm{ng} \mathrm{L}{ }^{-1}, 96.6 \pm 13.5 \%$, respectively, and no interfering peaks were observed in blank samples. Analyses were carried out using the same chromatographic conditions described earlier, with the exception of the temperature program, which was as follows: $150^{\circ} \mathrm{C}$ initial temperature, 2 -min hold, $10^{\circ} \mathrm{C} \mathrm{m^{-1 }}$ to $200^{\circ} \mathrm{C}, 3.5^{\circ} \mathrm{C} \mathrm{min}^{-1}$ to $270^{\circ} \mathrm{C}, 0.40^{\circ} \mathrm{C} \mathrm{min}{ }^{-1}$ to $275^{\circ} \mathrm{C}, 3.5$-min hold.

Copper concentrations were determined following the methods of Lindsay and Norvell (1978) and the American Public Health Association (1989). A detailed description of the copper levels measured in both the dissolved phase and particle phase of the runoff are discussed elsewhere (Rice et al., 2001).

\section{Particle-Phase Organic Pesticides}

A quarter of each filter from integrated water samples was extracted with 3:1 dichloromethane (DCM) and acetone (chromatographic grade) for $6 \mathrm{~h}$ using a Soxhlet apparatus. Extracts were cleaned up using an LC-Alumina-N 2-g (Supelco) cartridge topped with $1 \mathrm{~g}$ anhydrous $\mathrm{MgSO}_{4}$ to remove color, particle material, and water. An additional $15 \mathrm{~mL}$ of 1:1 DCM and acetone was passed through the cleanup column and combined with the extract. Extracts were reduced using a gentle stream of high-purity $\mathrm{N}_{2}$ gas and exchanged into isooctane. Extraction efficiency of the method was evaluated by spiking filter papers used to filter runoff water containing untreated soil with 2.5 to $3.0 \mu \mathrm{g}$ of target analytes and $2.7 \mu \mathrm{g}$ of dibutyl chlorendate (DBC) as a sample-specific extraction efficiency determination. Recoveries ranged from $85.3 \pm 4.9 \%$ for chlorothalonil to $91.2 \pm 10.1 \%$ for metribuzin. Blank filter papers were also extracted and analyzed with samples and no interfering peaks were found.

Extracts were analyzed using the chromatographic conditions described for dissolved-phase fenvalerate and esfenvalerate, with the exception of the temperature program, which was as follows: $150^{\circ} \mathrm{C}$ initial temperature, 2 -min hold, $10^{\circ} \mathrm{C}$ $\min ^{-1}$ to $200^{\circ} \mathrm{C}, 1$-min hold, $3.0^{\circ} \mathrm{C} \mathrm{min}^{-1}$ to $260^{\circ} \mathrm{C}, 10$-min hold, $7.0^{\circ} \mathrm{C} \mathrm{min}^{-1}$ to $280^{\circ} \mathrm{C}, 10$-min hold. The method detection limits for the target analytes were: chlorothalonil, $1.0 \mu \mathrm{g} \mathrm{L}^{-1}$; $\alpha$-endosulfan, $0.63 \mu \mathrm{g} \mathrm{L}{ }^{-1}$; $\beta$-endosulfan, $2.2 \mu \mathrm{g} \mathrm{L}^{-1}$; metribuzin, $0.39 \mu \mathrm{g} \mathrm{L}^{-1}$; fenvalerate, $550 \mu \mathrm{g} \mathrm{L}^{-1}$; and esfenvalerate, $49 \mu \mathrm{g} \mathrm{L}{ }^{-1}$.

\section{Statistical Analysis}

A randomized complete block design was used to assign each treatment (PT, VT, BC, VC) to four plots throughout the field. Analysis of variance (ANOVA) determined significant 
differences in runoff volume, soil loss, and pesticide loading from tomatoes grown in polyethylene (PT) and hairy vetch mulch (VT) for individual runoff events (Cochran and Cox, 1957; Steel and Torrie, 1980). The experiment was repeated for three consecutive field seasons with four replications of each treatment per season.

In addition, geometric means ( \pm standard deviation) of the 1997 to 1999 runoff data were calculated to facilitate the comparison of trends for pesticide concentrations and loads in the dissolved and particle phases of runoff from the two mulch systems (Campbell, 1985). The geometric means were more representative of the data sets than the arithmetic means as a result of several runoff events that contained pesticide concentrations that were orders of magnitude greater than typical runoff events.

\section{RESULTS AND DISCUSSION \\ Runoff Volume}

Runoff volumes were measured per plot, per event and the precipitation and average runoff volumes are shown in Fig. 1. During the 1997 and 1998 growing seasons the Mid-Atlantic region experienced drought conditions.
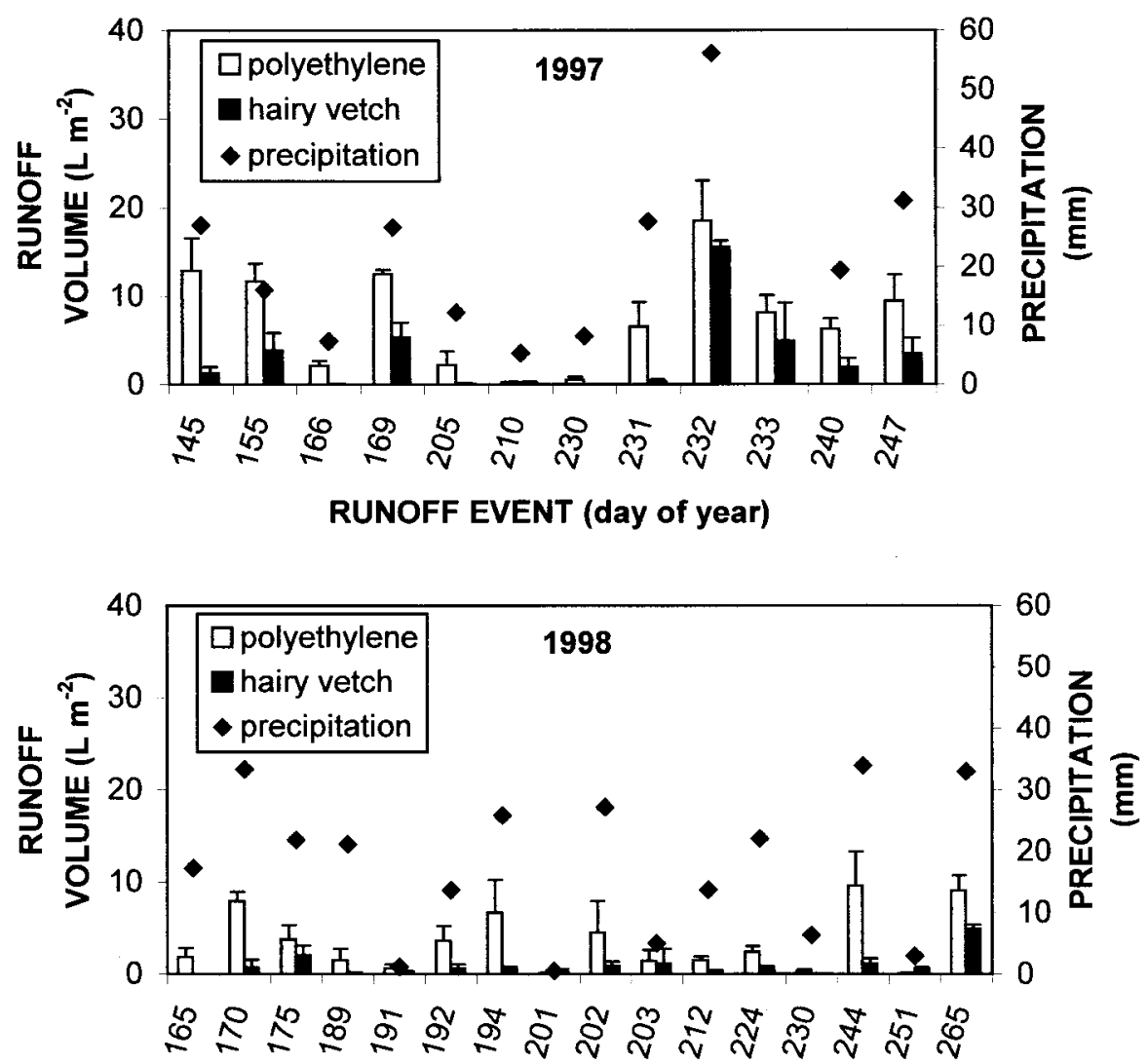

RUNOFF EVENT (day of year)

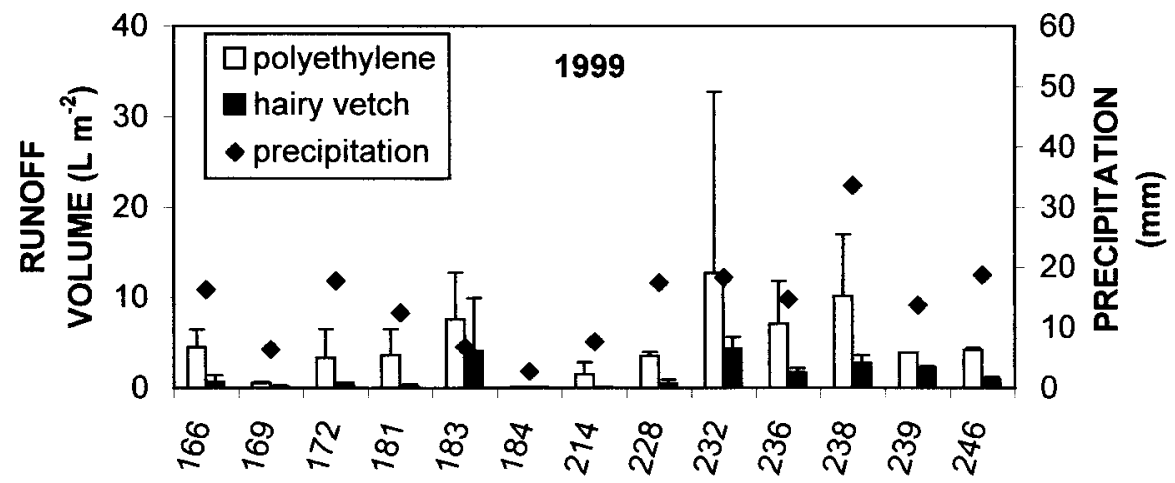

RUNOFF EVENT (day of year)

Fig. 1. Precipitation and runoff volume from polyethylene and hairy vetch mulch plots during the 3-yr study. The difference in runoff volume at each runoff event is significant $(p \leq 0.05)$ with the exception of runoff events 1997-210, 1998-201, and 1999-184. Error bars represent the standard deviation of the means. 
Therefore, a number of rain events were simulated using an overhead sprinkler to provide runoff for analysis. Runoff events occurring on Day of Year (DOY) 231 (19 August), 240, and 247 of 1997; DOY 170 (19 June), 192, 194, 224, and 244 of 1998; and DOY 246 (3 September) of 1999 were the result of simulated rainfall. Seventy-five, 69 , and $92 \%$ of the runoff events collected in the 1997, 1998, and 1999 field seasons resulted from natural precipitation.

With the exception of one runoff event in 1997, three events in 1998, and one event in 1999 where runoff volumes were similar for both treatments, the volume of runoff collected from polyethylene mulch plots was 2 to 100 times more than runoff from hairy vetch plots for individual runoff events. The seasonal water losses for the 1997 to 1999 growing seasons were 90.6, 55.4, and $146.0 \mathrm{~L} \mathrm{~m}^{-2}$ per growing season for polyethylene plots and $36.8,13.7$, and $75.7 \mathrm{~L} \mathrm{~m}^{-2}$ per growing season for hairy vetch plots, respectively. Rainfall rate and infiltration rate determines the overall quantity of surface
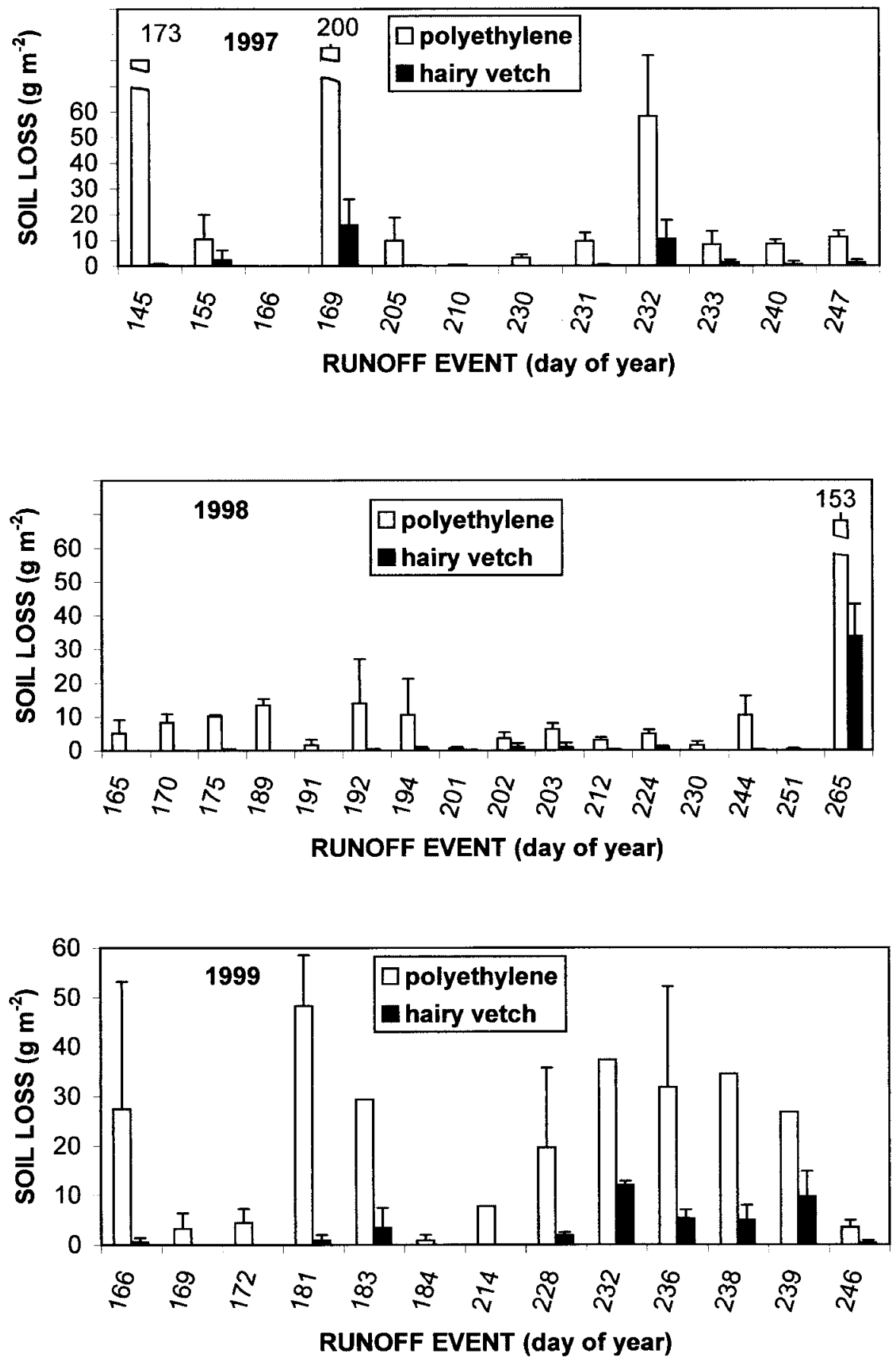

Fig. 2. Quantity of soil lost with runoff from polyethylene and hairy vetch mulch plots during the 3-yr study. The difference in soil loss at each runoff event is significant $(p \leq \mathbf{0 . 0 5}$ ) with the exception of runoff events 1997-210, 1998-201, and 1998-251. Error bars represent the standard deviation of the means. 
runoff. In plots containing polyethylene mulch, 50 and $75 \%$ of the soil surface is covered with the impermeable polyethylene, depending on the width of the plasticcovered tomato beds and bare-soil rows. The reduced infiltration capacity of the polyethylene plots results in increased runoff volume compared with hairy vetch plots that were covered with plant residues, which allow rainfall infiltration. Similar observations were reported in the research of McCall et al. (1988) and Wan and ElSwaify (1999), in which greater runoff volumes were associated with the use of impermeable plastic mulch relative to bare soil.

\section{Soil Erosion}

Soil loss $\left(\mathrm{g} \mathrm{m}^{-2}\right)$ was calculated based on the total volume of runoff water collected per plot per runoff event, the size of each plot, and the mass of filterable sediments per volume of runoff. Soil loss ranged from 0.27 to $200 \mathrm{~g} \mathrm{~m}^{-2}$ per event for polyethylene compared with 0.007 to $33.8 \mathrm{~g} \mathrm{~m}^{-2}$ per event for hairy vetch (Fig. 2). With the exception of one runoff event in 1998 where the values were comparable, the load of soil measured in individual runoff events from the polyethylene mulch plots was at least three times the amount measured in the runoff from the hairy vetch mulch plots. Ten percent of the runoff events delivered $>250$ times more soil from the polyethylene plots. The average soil loss for the 1997 to 1999 growing seasons was 492,247, and $535 \mathrm{~g}$ $\mathrm{m}^{-2}$ per season for polyethylene plots and $32.8,38.7$, and $118 \mathrm{~g} \mathrm{~m}^{-2}$ per season for hairy vetch mulch plots. The difference in soil loss between the two mulch systems was the result of both the increased runoff volume and greater concentration of suspended sediments associated with the polyethylene mulch plots. The greater runoff increased the opportunity for off-site transport of suspended sediments with runoff. In addition, the flow rate of runoff from the polyethylene plots was 1.2 to 7.5 times greater than hairy vetch plots, which resulted in suspended sediment concentrations that were four times greater in polyethylene runoff (geometric mean \pm standard deviation $=3334 \pm 0.87 \mathrm{mg} \mathrm{L}^{-1}$ for polyethylene plots and $692 \pm 1.5 \mathrm{mg} \mathrm{L}^{-1}$ for hairy vetch plots). Research has shown that the use of crop residues as an organic mulch dissipates the energy of rain drops and effectively reduces the velocity and amount of surface runoff (Mannering and Meyer, 1963; Foster and Meyer, 1972). A reduced runoff velocity or flow rate in plots containing hairy vetch residues may reduce the quantity of soil displaced with surface runoff and also allow more suspended sediments to settle out of the runoff, therefore reducing the suspended sediment concentration and soil loads. Similar observations have been noted in the research of Sur et al. (1992) and Zuzel and Pikul (1993), in which straw mulch significantly reduced runoff and soil loss from agricultural plots.

\section{Pesticide Concentration and Load}

\section{Dissolved-Phase Organic Pesticides}

In order to reduce the overall number of samples for analysis, equal portions of runoff water from each plot were combined into one integrated sample per plot for each rain event (eight integrated samples per event) and analyzed to compare results between treatments. Significantly $(p \leq 0.05)$ greater concentrations $\left(\mu \mathrm{g} \mathrm{L}^{-1}\right)$ of $\alpha$ - and $\beta$-endosulfan were detected in filtered runoff from polyethylene plots for 75 and $88 \%$, respectively, of runoff events collected following the application of the pesticide formulation. Greater concentrations of chlorothalonil were also detected in runoff from polyethylene plots; however, the levels were only significantly greater $(p \leq 0.05)$ in $46 \%$ of the events. In contrast, greater concentrations of metribuzin were detected in runoff from hairy vetch plots for $80 \%$ of the collected runoff events ( $40 \%$ significant at $p \leq 0.05)$. However, this is due to a $3: 1$ difference in the area of application between treatments. Metribuzin was applied to the entire plot area, tomato beds and rows, of the hairy vetch plots compared with only the bare-soil rows of the polyethylene plots. Esfenvalerate and fenvalerate were not detected in the filtered runoff water from either of the two mulch treatment. The range of dissolved-phase pesticide concentrations for individual runoff events occurring in the 1997, 1998, and 1999 field seasons and geometric mean of the pesticide concentrations for the three field seasons are presented in Table 1.

When runoff volumes were considered, significantly greater loads $\left(\mu \mathrm{g} \mathrm{m}^{-2}\right)$ of chlorothalonil and endosulfan

Table 1. Pesticide concentration in runoff from tomato plants grown in polyethylene or hairy vetch mulch.

\begin{tabular}{|c|c|c|c|c|}
\hline \multirow[b]{2}{*}{ Pesticide } & \multicolumn{2}{|c|}{ Polyethylene $\dagger$} & \multicolumn{2}{|c|}{ Hairy vetch $\dagger$} \\
\hline & Range & Mean (SD) $\div$ & Range & Mean (SD) $\div$ \\
\hline & \multicolumn{4}{|c|}{ Dissolved phase $\left(\mu \mathrm{g} \mathrm{L} \mathbf{L}^{-1}\right)$} \\
\hline Chlorothalonil & $30.87-510.8$ & $113.8(1.07)$ & $\overline{6.46}-494.8$ & $71.26(1.25)$ \\
\hline$\alpha$-Endosulfan & $0.33-10.68$ & $1.70(1.31)$ & $0.05-33.89$ & 0.94 (1.86) \\
\hline$\beta$-Endosulfan & $0.41-27.9$ & 2.59 (1.32) & $0.05-4.67$ & 0.67 (1.81) \\
\hline Esfenvalerate & $-\S$ & & $-\S$ & \\
\hline \multirow[t]{2}{*}{ Metribuzin } & $0.00-5.42$ & $0.14(2.57)$ & $0.04-5.30$ & 0.08 (1.09) \\
\hline & \multicolumn{4}{|c|}{ Particle phase $\left(\mu g g^{-1}\right)$} \\
\hline Chlorothalonil & $0.52-721302$ & $483.6(4.58)$ & $2.79-317381$ & $164.0(4.28)$ \\
\hline$\alpha$-Endosulfan & 0.01-14339 & $9.43(5.17)$ & $0.01-23200$ & $14.61(5.12)$ \\
\hline$\beta$-Endosulfan & $0.06-14722$ & $27.05(5.00)$ & $0.13-35666$ & $35.46(5.01)$ \\
\hline Esfenvalerate & $0.05-4941$ & $8.30(5.01)$ & $0.05-10260$ & $22.11(4.35)$ \\
\hline Metribuzin & $0.06-3.77$ & $0.41(1.76)$ & $1.31-19.28$ & $2.84(0.59)$ \\
\hline
\end{tabular}

$\dagger$ Data for the 1997, 1998, and 1999 field seasons.

$\$$ Geometric mean (standard deviation of the geometric mean).

$\S$ Below the limit of detection for esfenvalerate $\left(0.54 \mu \mathrm{g} \mathrm{L}^{-1}\right)$. 

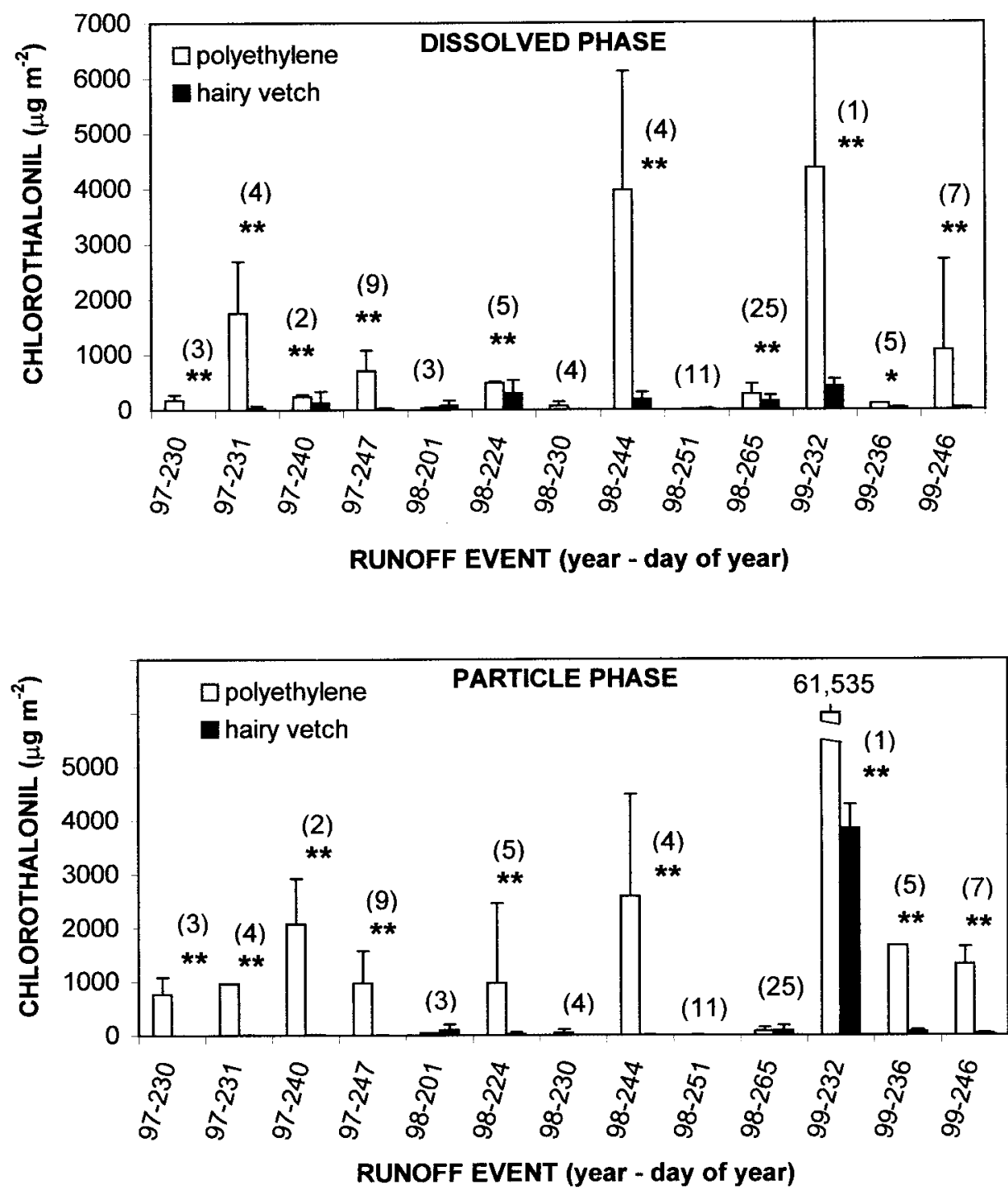

Fig. 3. Dissolved- and particle-phase loads of chlorothalonil in runoff following the application of Bravo 720 (a.i. chlorothalonil, $30.81 \mathrm{~g}$ per 162 $\mathbf{m}^{2}$ plot). Asterisk(s) represent a significant difference (* for $\boldsymbol{p}=\mathbf{0 . 0 5}$, ** for $\boldsymbol{p}=\mathbf{0 . 0 1}$ ) in pesticide load between mulch treatments for that runoff event. Numbers in parentheses represent days between application and runoff. Error bars represent the standard deviation of the means.

( $\alpha$ - and $\beta$-isomers) $(p \leq 0.05)$ were associated with the dissolved phase of runoff from polyethylene mulch as compared with hairy vetch (Fig. 3 to 5, Table 2). Statistical analyses of mean pesticide concentrations $\left(\mu \mathrm{g} \mathrm{L}^{-1}\right)$ from individual runoff events reveal that this difference in load $\left(\mu \mathrm{g} \mathrm{m}^{-2}\right)$ is due to significantly greater pesticide concentrations $(p \leq 0.05)$ in addition to larger runoff volumes (Table 1, Fig. 1). Correlation analysis of data collected in the first runoff events following pesticide application revealed that chlorothalonil loads were more attributed to runoff volume than dissolved-phase concentrations for both polyethylene and hairy vetch plots (polyethylene: $r=0.83$ volume, $r=0.00$ concentration; hairy vetch: $r=0.57$ volume, $r=0.06$ concentration). Runoff volume and dissolved-phase concentrations of $\alpha$ - and $\beta$-endosulfan were both important to endosulfan loads ( $\alpha$-endosulfan, polyethylene: $r=$ 0.76 volume, $r=0.88$ concentration; hairy vetch; $r=$ 0.92 volume, $r=0.99$ concentration) ( $\beta$-endosulfan, polyethylene: $r=0.48$ volume, $r=0.96$ concentration; hairy vetch: $r=0.86$ volume, $r=0.71$ concentration).

In contrast, comparable or greater loads of metribuzin were associated with the initial runoff from the hairy vetch plots, with the exception of one runoff event in 1998 (DOY 202) (Fig. 6). Although runoff volumes were larger from polyethylene plots, the greater concentrations of metribuzin in the hairy vetch runoff, as a result of the increased area of metribuzin application, resulted in similar or increased loads. The geometric means for loads of metribuzin were similar from polyethylene plots and hairy vetch plots (Table 2).

\section{Particle-Phase Organic Pesticides}

Overall, chlorothalonil concentrations on particles ( $\mu \mathrm{g}$ pesticide $\mathrm{g}^{-1}$ solids) filtered from composited runoff water samples were significantly greater $(p \leq 0.05)$ from the polyethylene plots than hairy vetch plots (Table 1 ). The reverse was true for esfenvalerate concentrations 

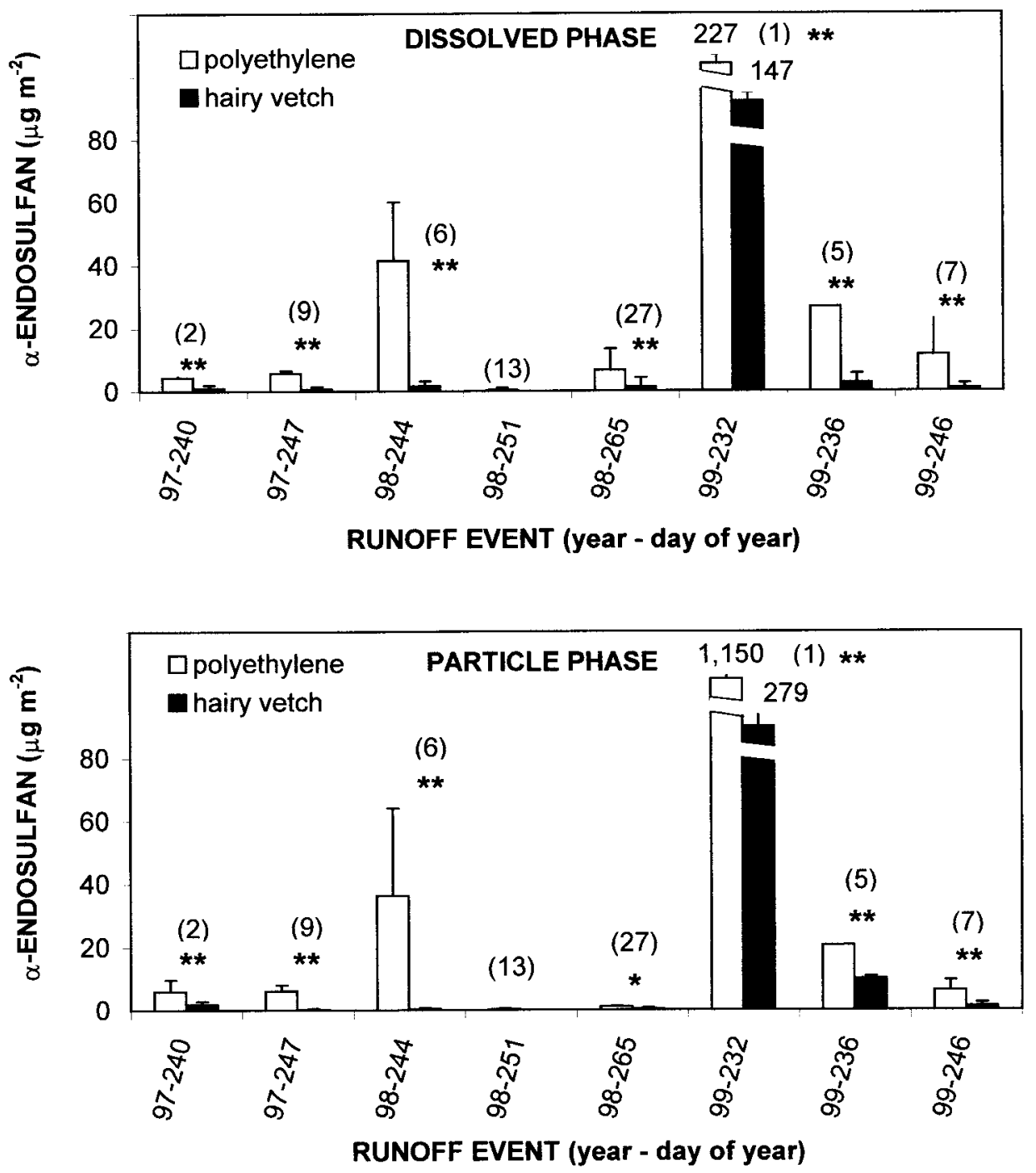

Fig. 4. Dissolved- and particle-phase loads of $\alpha$-endosulfan in runoff following the application of Thiodan 50 WP (a.i. endosulfan, $9.08 \mathrm{~g}$ per $162 \mathrm{~m}^{2}$ plot). Asterisk(s) represent a significant difference (* for $p=0.05$, ** for $p=0.01$ ) in pesticide load between mulch treatments for that runoff event. Numbers in parentheses represent days between application and runoff. Error bars represent the standard deviation of the means.

with the exception of one runoff event in 1999 (DOY 246). Similar to esfenvalerate, greater concentrations of endosulfan and metribuzin were associated with particles in runoff from hairy vetch plots than from polyethylene plots. However, this difference was only significant in 25,50 , and $20 \%$ of the runoff events for $\alpha$-endosulfan, $\beta$-endosulfan, and metribuzin, respectively $(p \leq 0.05)$. The same trends were noted with the comparison of geometric means for the particle-phase pesticide concentrations in runoff from polyethylene and hairy vetch plots (Table 1). Fenvalerate was not detected in the particle-phase runoff from either of the two mulch treatments.

Despite the greater concentrations of endosulfan and esfenvalerate associated with particles from the hairy vetch runoff, the increased quantity of sediments in the runoff from the polyethylene mulch plots resulted in total particle-phase loads $\left(\mu \mathrm{g} \mathrm{m}^{-2}\right)$ of chlorothalonil, endosulfan ( $\alpha$ - and $\beta$-isomers) and esfenvalerate that were two times to several orders of magnitude greater than from the hairy vetch plots (Fig. 3 to 5). In runoff events where esfenvalerate was detected, particle-phase loads ranged from 12.2 to $691 \mu \mathrm{g} \mathrm{m}^{-2}$ from polyethylene and 7.6 to $125 \mu \mathrm{g} \mathrm{m}^{-2}$ from hairy vetch plots (Fig. 7). The quantities of metribuzin transported with sediments in runoff from the hairy vetch and polyethylene mulch plots were comparable with the exception of one event occurring in 1998 (DOY 202) (Fig. 6). Geometric means of particle-phase loads in runoff from polyethylene and hairy vetch plots were similar for metribuzin but 4, 5, 8 , and 81 times greater in runoff from polyethylene plots for esfenvalerate, $\alpha$-endosulfan, $\beta$-endosulfan, and chlorothalonil, respectively (Table 2 ). Correlation analysis of the initial runoff event following the application of the pesticides revealed the following. The quantity of sediment lost with runoff attributed more to the particle phase load of metribuzin than the concentration of metribuzin associated with the particles from both mulch treatments (polyethylene $r=0.93$ soil loss, $r=0.46$ concentration; hairy vetch $r=0.99$ soil loss, $r=0.20$ 

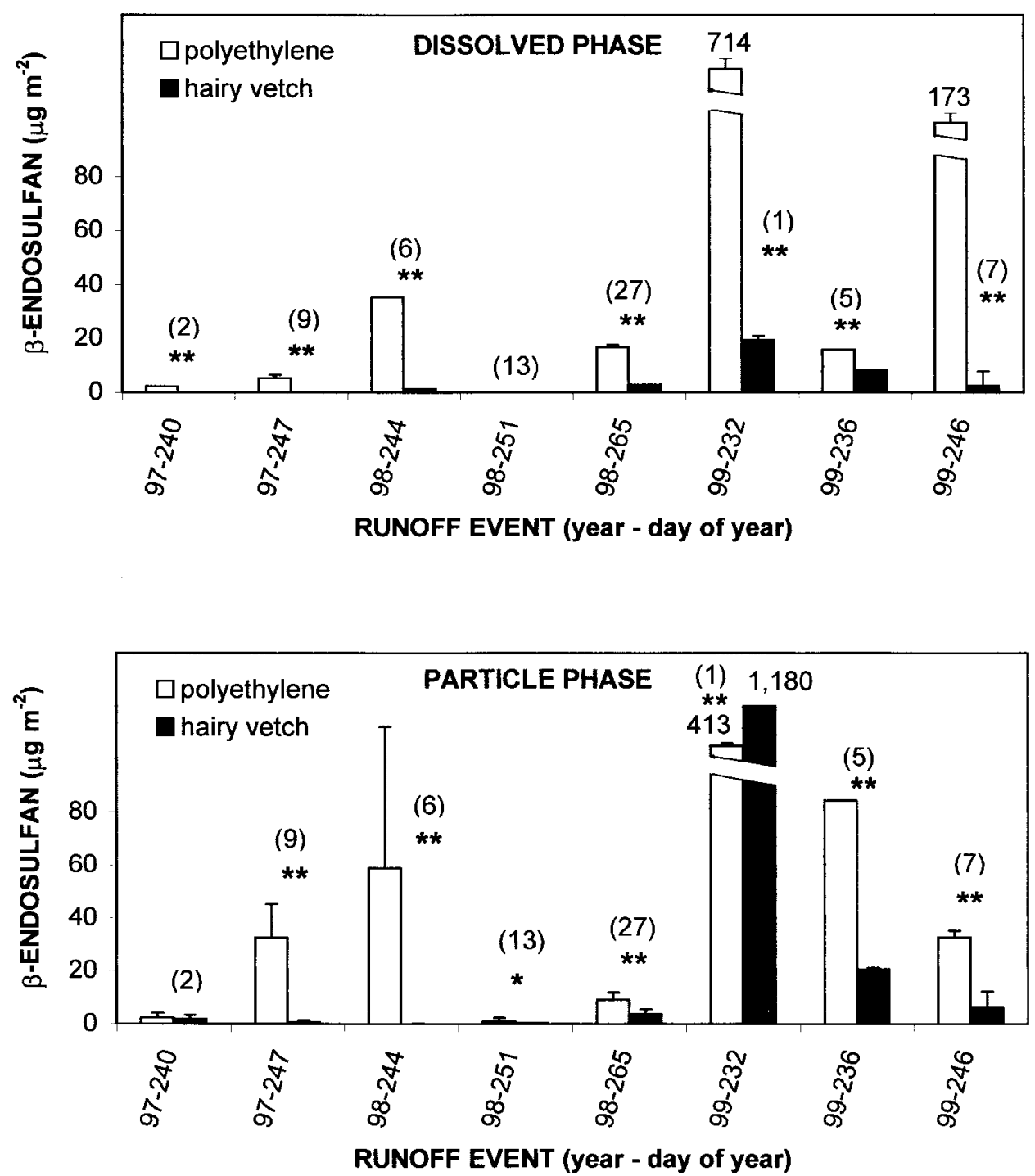

Fig. 5. Dissolved- and particle-phase loads of $\beta$-endosulfan in runoff following the application of Thiodan 50 WP (a.i. endosulfan, $9.08 \mathrm{~g}$ per $162 \mathrm{~m}^{2}$ plot). Asterisk(s) represent a significant difference (* for $\boldsymbol{p}=\mathbf{0 . 0 5}$, ** for $\boldsymbol{p}=\mathbf{0 . 0 1}$ ) in pesticide load between mulch treatments for that runoff event. Numbers in parentheses represent days between application and runoff. Error bars represent the standard deviation of the means.

concentration). Similar trends were noted in runoff from polyethylene mulch plots for chlorothalonil $(r=0.94$ soil loss, $r=0.71$ concentration) $\beta$-endosulfan $(r=0.97$ soil loss, $r=0.58$ concentration $)$ and esfenvalerate ( $r=0.96$ soil loss, $r=0.50$ concentration). Pesticide concentrations on the suspended sediments and the quantity of soil lost with runoff were equally important to particle phase loads of chlorothalonil ( $r=$ 0.99 soil loss, $r=0.91$ concentration $), \alpha$-endosulfan ( $r=$ 0.99 soil loss, $r=0.99$ concentration), and $\beta$-endosulfan ( $r=0.99$ soil loss, $r=0.91$ concentration) in runoff from hairy vetch plots and $\alpha$-endosulfan $(r=0.97$ soil loss, $r=0.97$ concentration) in runoff from polyethylene plots.

\section{Phase Distribution in Relation to Total Pesticide Load}

Loads of pesticides in the dissolved and particle phases of the runoff were compared to determine which fraction of the runoff contributed the most to the total pesticide load (Table 2). In those events following the application of endosulfan the observed ratio between the particle and dissolved phases varied between individual runoff events. However, the geometric means for the total endosulfan load (sum of the $\alpha$ - and $\beta$-isomer) were comparable, representing equal loading from both the dissolved and particulate phases. A comparison of geometric means for dissolved- and particle-phase loads of the $\alpha$ - and $\beta$-isomers revealed that greater loads of $\alpha$-endosulfan were detected in the dissolved phase while greater loads of $\beta$-endosulfan were detected in the particle phase, with a relatively small difference in loading between the two phases for both isomers ( $<$ three times). These observations were noted in runoff from both the polyethylene and hairy vetch plots.

A greater load of chlorothalonil was measured in the particle phase than the dissolved phase of runoff from polyethylene plots, but the difference between the geometric means was minimal ( $<$ two times). The reverse 
Table 2. Pesticide load in runoff from tomato plants grown in polyethylene or hairy vetch mulch.

\begin{tabular}{|c|c|c|c|c|}
\hline \multirow[b]{2}{*}{ Pesticide } & \multicolumn{2}{|c|}{ Polyethylene $\dagger$} & \multicolumn{2}{|c|}{ Hairy vetch $\dagger$} \\
\hline & Range & Mean (SD) $\ddagger$ & Range & Mean (SD) $)$ \\
\hline & \multicolumn{4}{|c|}{ Dissolved phase $\left(\mu \mathrm{g} \mathrm{m}^{-2}\right)$} \\
\hline Chlorothalonil & $2.63-4371$ & $287.7(2.04)$ & $0.00-417.5$ & $35.72(2.36)$ \\
\hline$\alpha$-Endosulfan & $0.40-226.9$ & $10.90(1.86)$ & $0.04-147.2$ & $1.50(2.25)$ \\
\hline$\beta$-Endosulfan & $0.12-713.9$ & $14.39(2.65)$ & $0.07-19.50$ & $1.19(2.00)$ \\
\hline Esfenvalerate & $-\S$ & & $-\S$ & \\
\hline \multirow[t]{2}{*}{ Metribuzin } & $0.00-26.50$ & $0.11(4.18)$ & $0.00-1.64$ & $0.07(3.57)$ \\
\hline & \multicolumn{4}{|c|}{$\underline{\text { Particle phase }\left(\mu \mathrm{g} \mathrm{m}^{-2}\right)}$} \\
\hline Chlorothalonil & $2.41-61535$ & $511.9(2.52)$ & 0.00-3 845 & $6.27(3.60)$ \\
\hline$\alpha$-Endosulfan & 0.19-1 150 & $6.67(2.01)$ & $0.04-278.6$ & $1.28(2.71)$ \\
\hline$\beta$-Endosulfan & $1.03-1180$ & $24.74(2.20)$ & $0.10-412.6$ & $3.11(2.60)$ \\
\hline Esfenvalerate & $0.00-690.5$ & $7.36(2.42)$ & $0.00-125.4$ & $1.96(2.24)$ \\
\hline \multirow[t]{2}{*}{ Metribuzin } & $0.38-213.5$ & $1.68(1.80)$ & $0.04-215.4$ & $1.21(2.69)$ \\
\hline & \multicolumn{4}{|c|}{ Total load $\left(\mu \mathrm{g} \mathrm{m}^{-2}\right)$} \\
\hline Chlorothalonil & 4.77-65906 & $799.6(4.56)$ & $0.56-4202$ & $41.99(5.96)$ \\
\hline$\alpha$-Endosulfan & 0.79-1 377 & 17.57 (3.87) & $0.08-420.4$ & 2.78 (4.96) \\
\hline$\beta$-Endosulfan & $0.24-1893$ & 39.13 (4.85) & $0.48-423.2$ & $4.30(4.60)$ \\
\hline Esfenvalerate & $0.00-690.5$ & $7.36(2.42)$ & $0.00-125.4$ & $1.96(2.24)$ \\
\hline Metribuzin & $0.39-214.1$ & $1.79(5.98)$ & $0.04-216.5$ & $1.28(6.26)$ \\
\hline
\end{tabular}

$\dagger$ Data for the 1997, 1998, and 1999 field seasons.

$\uparrow$ Geometric mean (standard deviation of the geometric mean).

$\S$ Below the limit of detection for esfenvalerate $\left(0.54 \mu \mathrm{g} \mathrm{L}^{-1}\right)$.

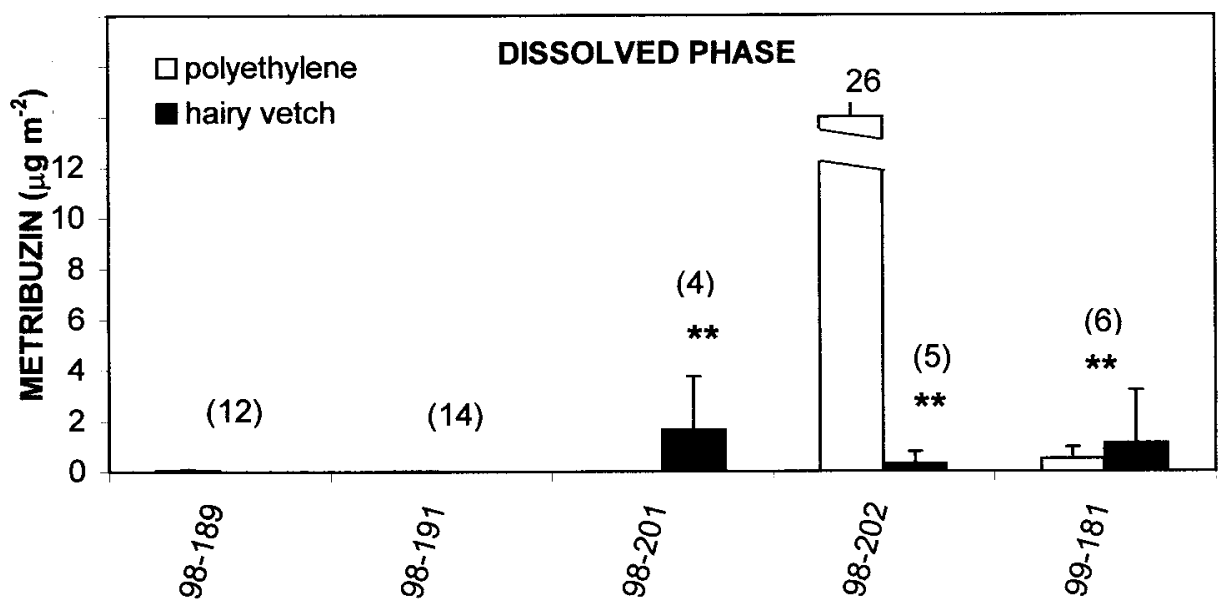

RUNOFF EVENT (year - day of year)

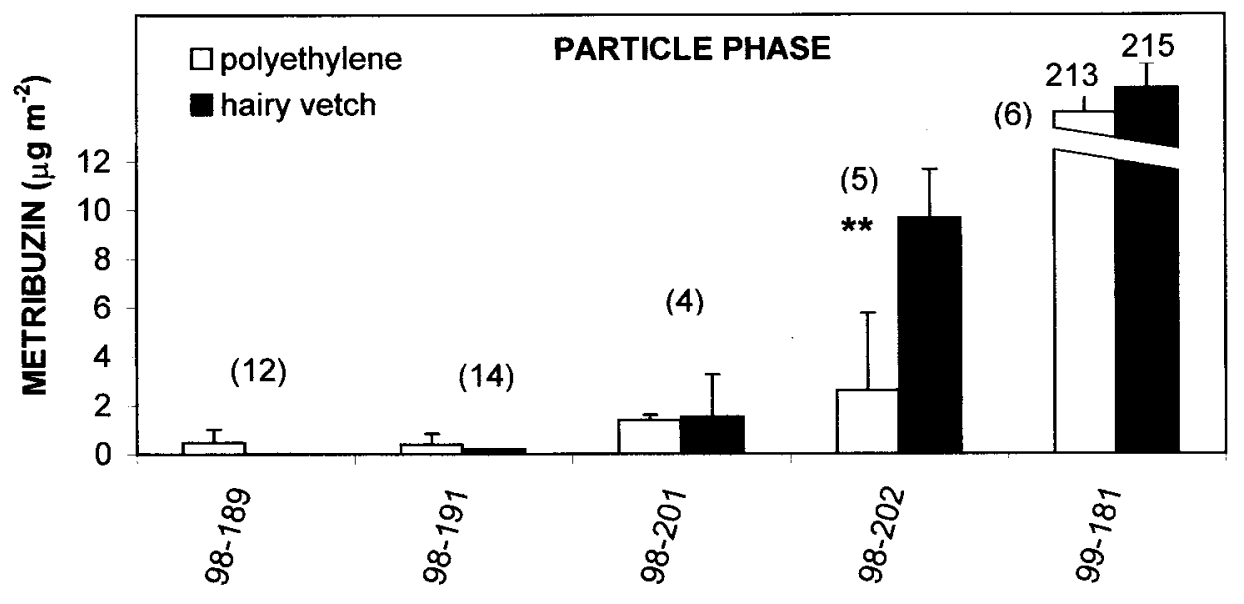

RUNOFF EVENT (year - day of year)

Fig. 6. Dissolved- and particle-phase loads of metribuzin in runoff following the application of Lexone DF (a.i. metribuzin, $6.81 \mathrm{~g}$ per $162 \mathrm{~m}^{2}$ plot). Asterisks represent a significant difference $(p=0.01)$ in pesticide load between mulch treatments for that runoff event. Numbers in parentheses represent days between application and runoff. Error bars represent the standard deviation of the means. 


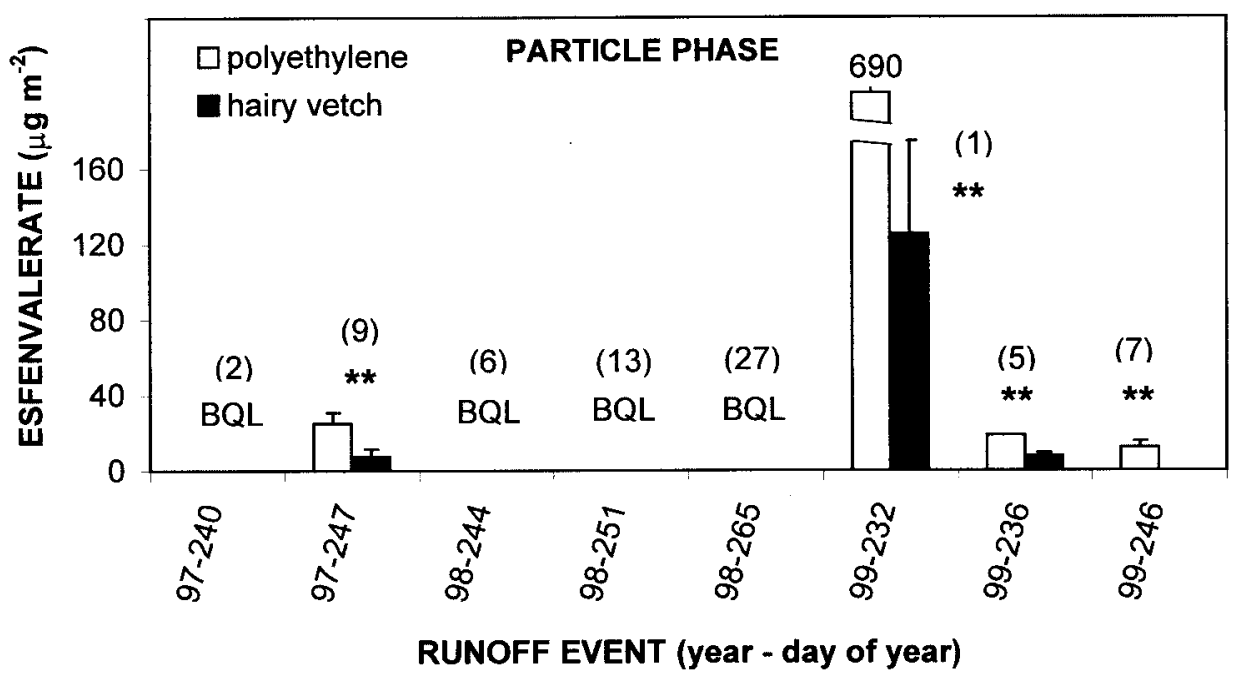

Fig. 7. Particle-phase loads of esfenvalerate in runoff following the application of Asana XL (a.i. esfenvalerate, $0.44 \mathrm{~g}$ per $162 \mathrm{~m}^{2}$ plot). Asterisks represent a significant difference $(p=0.01)$ in pesticide load between mulch treatments for that runoff event. Numbers in parentheses represent days between application and runoff. Error bars represent the standard deviation of the means. BQL $=$ below quantification limits.

was true for runoff from hairy vetch plots in which the geometric mean for chlorothalonil loading was five times greater in the dissolved phase than the particle phase. Particle-phase loads contributed the most to the total load of metribuzin in runoff from both polyethylene and hairy vetch plots. The means of the metribuzin loads were 15 and 17 times greater from the particle phase than the dissolved phase for polyethylene and hairy vetch plots, respectively. Total loads of esfenvalerate were equivalent to the particle-phase loads, as esfenvalerate was only detected in the particle phase of the runoff for both management practices. Additional studies of pesticide sorption interactions with polyethylene and vetch residue are needed to accurately predict and fully understand the phase distribution of pesticides in runoff from the two mulch systems.

\section{Total Pesticide Load}

Total loads, the sum of dissolved- and particle-phase loads, of chlorothalonil, $\alpha$-endosulfan, $\beta$-endosulfan, and esfenvalerate were significantly greater from polyethylene mulch plots than hairy vetch plots $(p \leq 0.05)$. Runoff from the two mulch systems contained comparable loads of metribuzin despite the three-times-greater area of application in the hairy vetch plots relative to the polyethylene plots (Table 2).

\section{Dissolved-Phase Loading Profiles from an Individual Rain Event}

The most important runoff events for pesticide loading occurred late in the season following the fungicide and insecticide applications when the greatest pesticide concentrations were observed. Individual runoff subsamples were analyzed for dissolved-phase pesticides and coupled with the flow data to estimate loads of pesticides with time. A representative example of this data is presented in Fig. 8 for runoff collected on DOY 244 from the 1998 season.

The difference in the loading profiles for the two treatments is evident for both chlorothalonil and endosulfan. The sorption of pesticides to polyethylene mulch may be playing a significant role in the loading profile of the runoff. If pesticides are strongly adsorbed to the plastic material, a slow bleed of chemicals off the plastic may be occurring over the entire event rather than a large pulse at the beginning followed by a steep decay rate. If a chemical is more weakly sorbed to the plastic, the loading profile may illustrate a large pulse at the beginning of the event followed by a sharp decline. McCall et al. (1988) noted that the peak concentration of endosulfan in runoff from black plastic plots occurred at the beginning of the rainfall event compared with the peak concentration in the bare soil runoff that occurred simultaneously with the peak flow. This indicated that endosulfan was more readily available from polyethylene than soil.

Interestingly, the loading rate of chlorothalonil for the polyethylene plots does not appear to be declining at the end of the sample period, as might be expected. However, this graph and our runoff sampling program only represent 58 and $75 \%$ of the events' total runoff from polyethylene and hairy vetch plots, respectively. This information also illustrates one of the limitations of this type of sampling. Because it is impossible to predict the intensity and duration of rainfall prior to the event, it is difficult to program the automated sampler to collect samples evenly throughout the entire event. Each sampler has a limited number of bottles that may be filled well before the end of the rain event.

There are a number of factors involved in the off-site transport and loading of pesticides with surface runoff. The quantity, phase distribution, and timing of pesticide loading with runoff can be influenced by the chemical properties of the pesticide, interaction of the pesticide with soil and mulch, and the availability of the pesticide to be transported with runoff in the water phase or attached to suspended sediments.

With the exception of the preemergent herbicide (metribuzin), which is applied to the bare soil or soil covered 

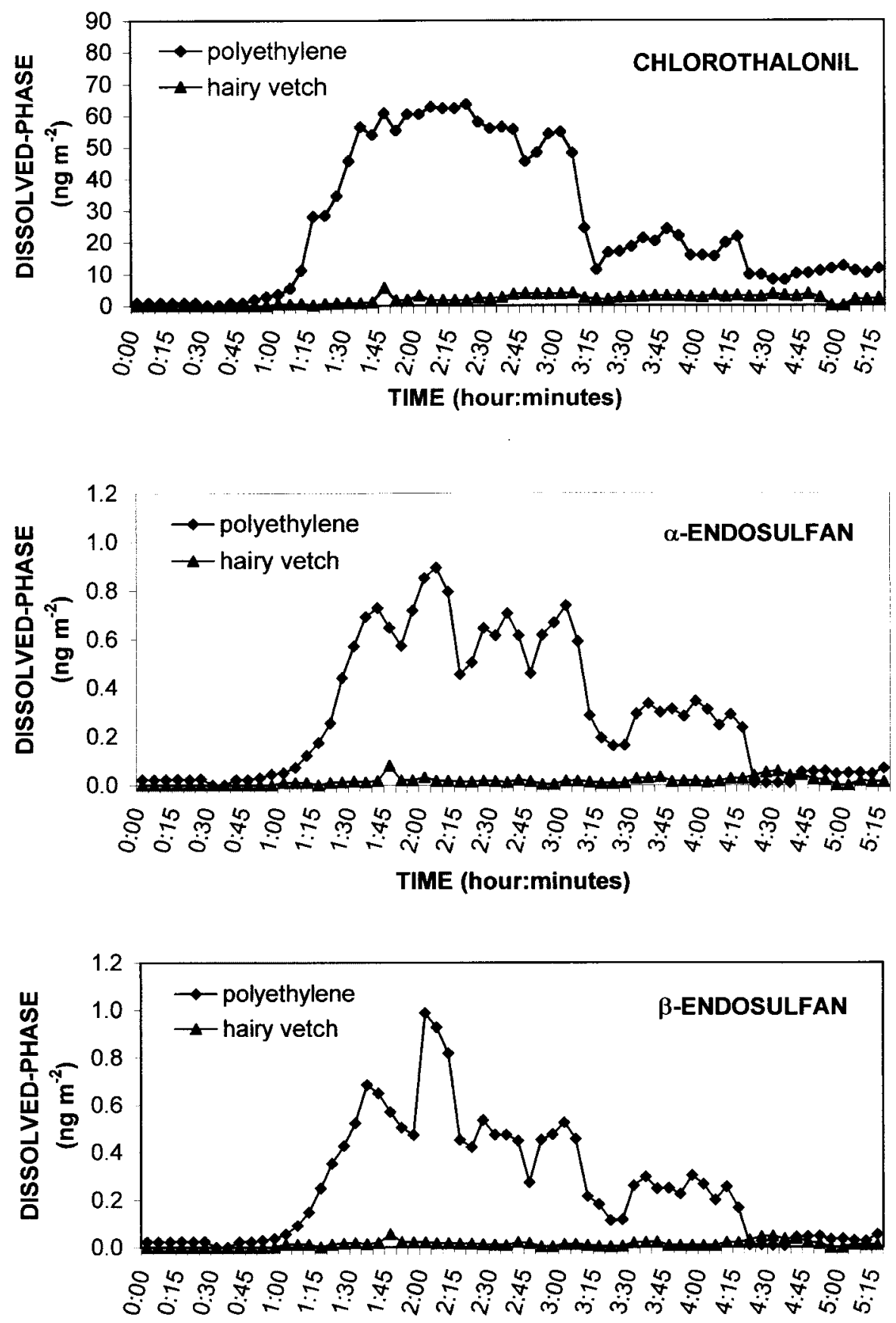

TIME (hour:minutes)

Fig. 8. Dissolved-phase loading of chlorothalonil, $\alpha$-endosulfan, and $\beta$-endosulfan with time. The runoff event occurred in 1998 on Day of Year 244, which was $4 \mathrm{~d}$ following the application of chlorothalonil and endosulfan.

with vetch residue, the fungicide (chlorothalonil) and insecticides (endosulfan, esfenvalerate) were applied to the tomato plants. Inevitably, a percent of the applied pesticides are either washed off the foliage onto the mulch or are directly applied to the mulch during foliar application. Adsorption-desorption of pesticides to the mulch will influence the agrochemicals' availability to be transported with surface runoff. Sorption of pesticides to polyethylene has been shown to be influenced by the chemical properties of the pesticide as well as the density of the polyethylene (Vuik et al., 1990; Topp and Smith, 1992). In order to fully understand pesticide transport with runoff in the two mulch systems, additional studies of pesticide-vetch residue and pesticidepolyethylene sorption interactions are needed.

Total pesticide loads with runoff are equivalent to the volume of carrier, suspended particle and/or water, times the concentration of pesticide associated with that carrier. Research has shown that rainfall may interact with agrochemicals on the top centimeter of soil, termed the mixing zone or extraction zone. The greater the time between the initiation of rainfall and runoff, the 
more time the pesticide has to infiltrate into the soil, which will reduce the availability and therefore the quantity of agrochemicals that are transported with surface runoff (Iowa State University, 1992; Baker and Mickelson, 1994; Wauchope, 1996). Because the infiltration rate relative to rainfall rate determines the overall quantity of surface runoff, the reduced infiltration capacity of the polyethylene plots and the reduction of pesticides leaching below the extraction zone explains, in part, the increased runoff volume and greater concentration of pesticides measured in runoff from polyethylene mulch. Management practices that reduce or enhance either runoff volume or soil loss will influence pesticide loading.

\section{CONCLUSION}

Our side-by-side instrumented field plots have shown that significantly greater volumes of runoff water were collected from plots containing polyethylene mulch $(p \leq$ 0.05 ). Associated with the additional runoff volume was greater soil erosion and increased off-site loading of pesticides in both the dissolved and particle phase of runoff. There is concern that runoff from fresh-market vegetable production, particularly from management practices with polyethylene mulch, contributes to water quality degradation and adverse effects on shellfish and other aquatic organisms. Our study comparing polyethylene mulch with a vegetative mulch and the research of McCall et al. (1988) and Wan and El-Swaify (1999) comparing polyethylene mulch with bare soil revealed that greater runoff volumes are associated with the impermeable polyethylene mulch. In addition, our comparative study has shown significantly $(p \leq 0.05)$ greater loads of soil and pesticides with runoff from polyethylene plots, which suggest that this management practice will have greater adverse effect on the surrounding environment. Our speculation was confirmed with the research of Hetzer et al. (1999, 2000), in which runoff collected from the same polyethylene plots proved to be more toxic to aquatic organisms than runoff from the more permeable hairy vetch mulch. The vegetative mulch reduced both sediment-bound and dissolved chemical loads, which reduced exposure and detrimental effects to growth and development, growth and survival, and survival and reproduction of diatom (Thalassiosira psuedonana), amphipod (Leptochierus plumulosus), and copepod (Eurytemora affinis), respectively. In order to reduce the environmental impact of vegetable production, we need to reduce runoff volumes leaving agricultural areas. This may require the adoption of different management practices that (i) replace the impermeable polyethylene mulch with a mulch that allows greater rainfall infiltration or (ii) maintain the use of polyethylene mulch with the addition of vegetative rows between polyethylene mulch beds or vegetative strips along the edge of the fields, to retard and reduce runoff from polyethylene mulch systems. A reduction in runoff volume would reduce soil erosion along with particleand dissolved-phase pesticide loads.

\section{ACKNOWLEDGMENTS}

The authors would like to thank Bob Wevadu, Rachel Herbert, Cumberland Dugan, Alex Richeal, and Cristina Nochetto for their assistance in maintaining the tomato plots and/or the processing, extraction, and analysis of field samples.

\section{REFERENCES}

Abdul-Baki, A.A., and J.R. Teasdale. 1997. Sustainable production of fresh-market tomatoes and other summer vegetables with organic mulches. Farmers' Bull. 2279. USDA Agric. Res. Serv., Washington, DC.

Abdul-Baki, A.A., J.R. Teasdale, and R.F. Korcak. 1997. Nitrogen requirements of fresh-market tomatoes on hairy vetch and black polyethylene mulch. HortScience 32:217-221.

Abdul-Baki, A.A., J.R. Teasdale, R.F. Korcak, D.J. Chitwood, and R.N. Huettel. 1996. Fresh-market tomato production in a low-input alternative system using cover-crop mulch. HortScience 31:65-69.

American Public Health Association. 1989. Standard methods for the examination of water and wastewater. 17th ed. APHA, Washington, DC.

Baker, D.B., and R.P. Richards. 1990. Transport of soluble pesticides through drainage networks in large agricultural river basins. $p$. 241-270. In D.A. Kurtz (ed.) Long range transport of pesticides. Lewis Publ., Chelsea, MI.

Baker, J.L., and S.K. Mickelson. 1994. Application technology and best management practices for minimizing herbicide runoff. Weed Technol. 8:862-869.

Baughman, D.S., D.W. Moore, and G.I. Scott. 1989. A comparison and evaluation of field and laboratory toxicity tests with fenvalerate on an estuarine crustacean. Environ. Toxicol. Chem. 8:417-429.

Campbell, G.S. 1985. Soil physics with basic: Transport models for soil-plant systems. Elsevier, New York.

Chandler, G.T., and G.I. Scott. 1991. Effects of sediment-bound endosulfan on survival, reproduction and larval settlement of meiobenthic polychaetes and copepods. Environ. Toxicol. Chem. 10:375382.

Clark, J.R., M.A. Lewis, and A.S. Pait. 1993. Pesticide inputs and risks in coastal wetlands. Environ. Toxicol. Chem. 12:2225-2233.

Cochran, W.G., and G.M. Cox. 1957. Experimental designs. 2nd ed. John Wiley \& Sons, New York.

Dao, T.H. 1991. Field decay of wheat straw and its effects on metribuzin and S-ethyl metribuzin sorption and elution from crop residues. J. Environ. Qual. 20:203-208.

Davis, R.M., G. Hamilton, W.T. Lanini, T.H. Screen, and C. Osteen 1998. The importance of pesticides and other pest management practices in U.S. tomato production. USDA Natl. Agric. Pestic. Impact Assessment Program. Doc. I-CA-98. U.S. Gov. Print Office, Washington, DC.

Dell, C.J., C.S. Throssell, M. Bischoff, and R.F. Turco. 1994. Estimation of sorption coefficients for fungicides in soil and turfgrass thatch. J. Environ. Qual. 23:92-96.

Foster, G.L., and L.D. Meyer. 1972. Erosion mechanics of mulches. Am. Soc. Agric. Eng. Paper no. 72-754. ASAE, St. Joseph, MI.

Ghadiri, H., P.J. Shea, and G.A. Wicks. 1984. Interception and retention of atrazine by wheat (Triticum aestivum) stubble. Weed Sci. 32:24-27.

Hetzer, P.R., S.S. Brown, P.J. Rice, J.E. Baker, and J.A. HarmonFetcho. 2000. Comparative effects of cultivation practices (vegetative vs. polyethylene mulch) on pesticide-related ambient toxicity in estuarine habitats. Abstract 141. In Picogram and Abstracts no. 59, Discussion of Agrochemicals, 220th Am. Chem. Soc. Natl. Meeting, Washington, DC. 20-24 August 2000. ACS, Washington, DC.

Hetzer, P.R., P.J. Rice, S.S. Brown, and J.E. Baker. 1999. Effects of pesticides in runoff water from organic mulch and plasticulture treated tomato plots on estuarine organisms. p. 108. In Annu. Meeting, Soc. Environ. Toxicol. Chem., Philadelphia, PA. 14-18 Nov. 1999. SETAC Press, Pensacola, FL.

Iowa State University. 1992. Understanding and reducing pesticide losses. Pm-1495. Iowa State Univ. Ext., Ames.

Johnson, W.E., R.B. Kroll, J.R. Plimmer, and A.S. Pait. 1994. The occurrence and distribution of pesticides in Chesapeake Bay. p. 
105-145. In S. Nelson and P. Elliott (ed.) Perspectives on Chesapeake Bay, 1994: Advances in estuarine sciences. CRC Publ. no. 147. Chesapeake Res. Consortium, Edgewater, MD.

Kelly, T.C., Y.-C. Lu, A.A. Abdul-Baki, and J.R. Teasdale. 1995. Economics of a hairy vetch mulch system for producing freshmarket tomatoes in the Mid-Atlantic region. J. Am. Soc. Hortic. Sci. 120:854-860.

Lindsay, W.L., and W.A. Norvell. 1978. Development of a DTPA test for zinc, iron, manganese, and copper. Soil Sci. Soc. Am. J. 42: 421-428.

Mannering, J.V., and L.D. Meyer. 1963. The effect of various rates of surface mulch on infiltration and erosion. Soil Sci. Soc. Am. Proc. 27:84-86.

McCall, E.C., Jr., G.I. Scott, and J.M. Hurley. 1988. A comparison of agricultural nonpoint source runoff from black plastic and conventional-till tomato test plots. South Carolina Water Resour. Res. Inst. Tech. Completion Rep. G1251-07. Rep. no. 126. Clemson Univ., Clemson, SC.

McConnell, L.L., C.B. Nochetto, and P.J. Rice. 1998. Solid-phase microextraction of metribuzin, chlorothalonil, endosulfan and esfenvalerate in runoff water from tomato production. p. 216. In Annu. Meeting, Soc. Environ. Toxicol. Chem., Charlotte, NC 15-19 Nov. 1998. SETAC Press, Pensacola, FL.

McVay, K.A., D.E. Radcliffe, and W.L. Hargrove. 1989. Winter legume effects on soil properties and nitrogen fertilizer requirements. Soil Sci. Soc. Am. J. 53:1856-1862.

Nerin, C., A.R. Tornes, C. Domeno, and J. Cacho. 1996. Adsorption of pesticides on plastic films used as agricultural soil covers. J. Agric. Food Chem. 44:4009-4014.

Pait, A.S., A.E. De Souza, and D.R.G. Farrow. 1992. Agricultural pesticide use in coastal areas: A national summary. ORCA/NOS/ NOAA, Rockville, MD.

Ranells, N.N., and M.G. Wagger. 1996. Nitrogen release from grass and legume cover crop monocultures and bicultures. Agron. J. 88: 777-782.

Rice, P.J., L.L. McConnell, L.P. Heighton, A.M. Sadeghi, A.R. Isensee, J.R. Teasdale, A.A. Abdul-Baki, J.A. Harman-Fetcho, and C.J. Hapeman. 2001. Comparison of copper levels in runoff from fresh-market vegetable production using polyethylene mulch or a vegetative mulch. Environ. Toxicol. Chem. (in press).

Savitz, J.D., D.A. Wright, and R.A. Smucker. 1994. Toxic effects of the insecticide Diflubenzuron (Dimilin) on survival and development of nauplii of the estuarine copepod, Eurytemora affinis. Mar. Environ. Res. 37:297-312.

Scott, G.I., D.S. Baughman, A.H. Trim, and J.C. Dee. 1987. Lethal and sublethal effects of insecticides commonly found in nonpoint source agricultural runoff to estuarine fish and shellfish. p. 251-273.
In W.B. Vernberg et al. (ed.) Pollution physiology of estuarine organisms. Univ. of South Carolina Press, Columbia.

Scott, G.I., M.H. Fulton, D.W. Moore, G.T. Chandler, T.F. Bidleman, P.B. Key, T.W. Hampton, J.M. Marcus, K.L. Jackson, D.S. Baughman, A.H. Trim, L. Williams, C.J. Louden, and E.R. Patterson. 1990. Agricultural insecticide runoff effects on estuarine organisms: Correlating laboratory and field toxicity testing with ecotoxicological biomonitoring. Rep. CR-813138-02-1. USEPA, Gulf Breeze, FL.

Smith, M.S., W.W. Frye, and J.J. Varco. 1987. Legume winter cover crops. Adv. Soil Sci. 7:95-139.

Steel, R.G.D., and J.H. Torrie. 1980. Principles and procedures of statistics: A biometrical approach. 2nd ed. McGraw-Hill, New York.

Stevenson, J.C., K. Staver, and R. Brinsfield. 1986. Surface runoff and groundwater impacts from agricultural activities in the Chesapeake region. p. 211-219. In J.B. Summers and S.S. Anderson (ed.) Toxic substances in agricultural water supply and drainage: Defining the problems. U.S. Committee on Irrigation and Drainage, Denver, CO.

Sur, H.S., P.S. Mastana, and M.S. Hadda. 1992. Effect of rates and modes of mulch application on runoff, sediment and nitrogen loss on cropped and uncropped fields. Trop. Agric. 69:319-322.

Teasdale, J.R. 1996. Contribution of cover crops to weed management in sustainable agricultural systems. J. Prod. Agric. 9:475-479.

Topp, E., and W. Smith. 1992. Sorption of the herbicides atrazine and metolachlor to selected plastics and silicone rubber. J. Environ. Qual. 21:316-317.

USEPA. 1990. National water quality inventory, 1988. USEPA Rep. 440/5-90/003. U.S. Gov. Print. Office, Washington, DC.

Vuik, J., J.M. van der Poll, R. Vink, and R.H. de Vos. 1990. Adsorption experiments of etridiazole and oxamyl on polyethylene sheets and poly(vinyl chloride) tubing used in horticulture. J. Agric. Food Chem. 38:328-330.

Wagger, M.G. 1989. Time of desiccation effects on plant composition and subsequent nitrogen release from several winter annual cover crops. Agron. J. 81:236-241.

Wan, Y., and S.A. El-Swaify. 1999. Runoff and soil erosion as affected by plastic mulch in a Hawaiian pineapple field. Soil Till. Res. 52:2935.

Wauchope, R.D. 1978. The pesticide content of surface water draining from agricultural fields: A review. J. Environ. Qual. 7:459-472.

Wauchope, R.D. 1996. Pesticides in runoff: Measurement, modeling, and mitigation. J. Environ. Sci. Health B31:337-344.

Webster, E.P., and D.R. Shaw. 1996. Impact of vegetative filter strips on herbicide loss in runoff from soybean (Glycine max). Weed Sci. 44:662-671.

Zuzel, J.F., and J.L. Pikul, Jr. 1993. Effects of straw mulch on runoff and erosion from small agricultural plots in northeastern Oregon. Soil Sci. 156:111-117. 